DOI: https://doi.org/10.31933/dijemss.v2i3

Received: $27^{\text {th }}$ November2020, Revised: $15^{\text {th }}$ January 2021 , Publish: $12^{\text {nd }}$ February 2021

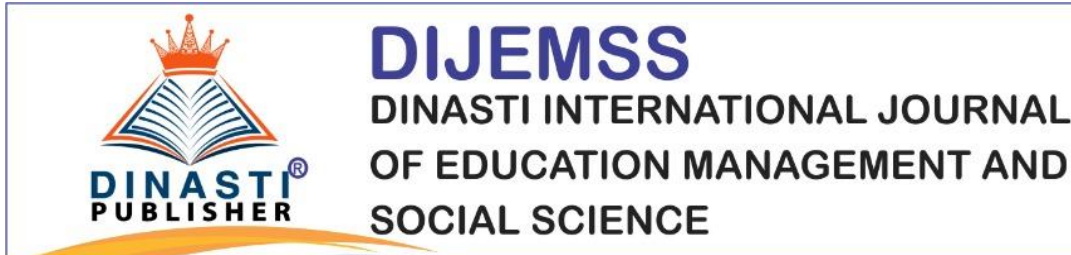

https://dinastipub.org/DIJEMSS editor@dinastipub.org 08117401455 (C)

\title{
RECLAMATION OF EX-PETI AGRICULTURAL LAND IN MERANGIN DISTRICT (CASE STUDY IN PANGKALANJAMBUDISTRICT MERANGIN REGENCY, JAMBI PROVINCE IN 2020)
}

\author{
Arislan Arislan', M. Syukurman², Mardalena Mardalena ${ }^{3}$ \\ 1) Kesmas STIKes Merangin, Ind onesia. lanarisbaimansaid @ gmail.com \\ 2) PLS STKIP YPM, Indonesia. syukurmanm@yahoo.co.id \\ 3) Pendidikan Ekonomi STKIP YPM Bangko, Ind onesia. Mardalena17@ gmail.com
}

Corresponding Author: Mardalena Mardalena ${ }^{3}$

\begin{abstract}
Unlicensed gold mining (PETI) is rife in the community, especially entrepreneurs / capital owners since the last ten years in Merangin Regency. Lack of awareness of negative impacts is a problem that needs serious attention from the government. There are miners who come from outside and from the community itself. Even though PETI is difficult to overcome, many of the people who own the land have processed it to be planted with rice again. In other places or areas in Indonesia, many exPETI lands cannot be planted with rice anymore because they have already contaminated with mercury. Due to the fact that many ex-PETI lands have been re-processed into paddy fields in Merangin Regency, a research was conducted which took place in Pangkalan Jambu District. The reason for choosing Pangkalan Jambu sub-district as the research location is because in this sub-district the largest area of land in Merangin Regency is being mined by the community. The research was conducted with a case study qualitative approach with data collection techniques, observation, interviews and documentation. The purpose of this study was to examine the processing of ex-PETI rice fields in to reclamation. The results of the study concluded that the reclamation activity was carried out after several landowners tried to plant rice on the ex-PETI land which was successful and did not encounter any significant obstacles. Starting from here, other residents did the same thing and it turns out that it continues to grow until now. As the reason why rice plants can thrive, it turns out that in this place the miners do not use mercury when mining. Previously, the area of productive rice fields was 1202 ha and now, of the eight villages, the number of rice fields that have been reproducing (reclaimed) is 139 ha. The re are 804 ha of rice fields damaged by PETI and there are 259 ha of land that are not damaged but have not yet operated or have not recovered and need to be reclaimed again.
\end{abstract}

Keywords: ex-card land reclamation.

\section{INTRODUCTION}

Merangin Regency is one of the regencies in Jambi Province with an area of $1 \mathrm{k}$. $7,679.00 \mathrm{~km} 2$ or 767,900 ha, consisting of 24 sub-districts and 2015 villages / kelurahan and a total population of 388,928 with a population distribution of 51 people / $\mathrm{km} 2$ and with different 
potentials from one sub-district to another. The differences referred to include differences in the potential for natural resources, human resources, socio-culture and so on.

Judging from its geographical location, Merangin District is in a position between 1020 - 1040 east longitude and 20 - 30 south latitude. According to the topography, most of the area consists of lowlands, while to the west with a flat topography, undulating to hilly and mountainous. The largest area in Merangin Regency is an area with an altitude of 500 to> 1,000 $\mathrm{m}$ above sea level.

Land resources in Merangin Regency based on its topography, structure and texture consist of several types, namely: podsolid, latosol, andosol, organosol, glei humus and complex soil. Judging from the land, the largest area is land from podsolid and latosol types. Based on Oldeman's provisions, Merangin Regency is a type B2 climate classification.

According to the estimated land potential and utilization area figures compiled from the sub-district report that the potential for dry land is 181,134 ha, 13,732 ha of rice fields, with an area of 141,075 ha of dry land use with an area of 10,314 ha of paddy land. dry land is 40,059 ha and untapped paddy land is 3,418 ha.

If we look at it from the workforce side, it turns out that there are still many workers who do not have the lifes skills expected in the era of globalization. With increasingly competitive competition in various fields of community life, intelligence is needed for the workforce and of course expecting the role of the government, the business world and / or industry, universities and other stakeholders so that it is hoped that there will be an increase in competitiveness in doing business in society.

On the other hand, the majority of community businesses in Merangin Regency are in the agricultural sector. Agriculture, in a broad sense, is the human activity to obtain products derived from plants and / or animals which was initially achieved by deliberately perfecting all the possibilities provided by nature in order to reproduce these plants and / or animals (Aarsten, 1953).

The people of Merangin generally consume agricultural products as staple food. Recently, a problem has emerged, namely the existence of unlicensed gold mining, abbreviated as PETI, which is rife and very difficult to stop.

Rice production in Merangin Regency is still not optimal, especially if it is processed from PETI which causes the environment to become unstable, especially for agricultural land. The area of agricultural land due to PETI is getting smaller because it cannot be used anymore. This is the biggest challenge today that must be faced by the government and affected communities.

Agricultural land damaged by PETI includes rice fields, plantations, moor, yards, fields and others. Agricultural products are very diverse including rice, alvocad, coffee, corn, onions, cloves, cocoa, nuts, rubber, cinnamon, soybeans, coconut, palm oil, potatoes, yams, sweet potatoes, sago and others. 
Pangkalan Jambu sub-district is one of the sub-districts that has a very large area of agricultural land and is the largest area affected by PETI. This sub-district has land that is dominated by rice fields and gardens (rubber and oil palm). Therefore, most of the people in this area are farmers so that Pangkalan Jambu District is an area known as the food hull area of Merangin Regency.

The word "mining" refers to the adjective that is mining. Based on the Minerba Law No.4 of 2009, mining is part or all of the stages of activity in the framework of research, management and exploitation of minerals or coal which include general investigations, exploration, feasibility studies, construction, mining, processing and refining, transportation and sales. as well as post-mining activities.

In Merangin District, it can be said that in general gold miners do not have a license. They can already be said to have violated the law, but on average they are not legally processed and this is a dilemma. Apart from these problems, members of the community who own the exmining land are trying to return their land to its original function so that it can later be used as agricultural land or otherwise. Therefore, post-mining land reclamation should be done. Reclamation is an activity carried out to organize, restore and improve the quality of the environment and ecosystem so that it can function again according to its purpose.

Recently, the fact is, in Merangin District that some of the ex-mining land has gradually been reused as productive land for lowland rice cultivation by local residents. Therefore, researchers are interested in conducting research with the title: "Reclamation of Ex-Mining Gold Tampa Permit (PETI) Agricultural Land in Merangin District (Case Study in Pangkalan Jambu Subdistrict, Merangin District, Jambi Province, 2020)".

\section{LITERATURE REVIEW Empowerment Theory}

According to the theory of psychology, humans have various powers, namely the power or power to think, behave, and act. These powers must be developed in humans and human groups so that their level of power is optimal to change themselves and their environment. Community empowerment is essentially the same as community development, which includes:

1. Approach to society as a whole. This approach is based on broad participation, society as a central concept, and requires a holistic approach.

2. Approach based on independence.

3. A specific problem-solving approach.

4. Demonstrative approach.

5. Experimental approach.

6. Power conflict approach.

So far, development has given birth to a number of "services to the community": meanwhile development oriented to community empowerment will give birth to "society into service". Empowering communities is not just "mobilizing people to take part"; it is to "pursue a network of partnerships". The focus of community empowerment is family oriented. This empowerment contains: (1) building internal family capacity (knowledge, skills, attitudes, etc.); (2) changing beliefs and attitudes that hinder progress (early marriage, disciplinary 
violations, and crime); and (3) strengthening traditional values that are conducive to development (mutual cooperation, respect), and filtering new values. Community and family empowerment strategies and building partnerships need to be based on the following:

1. A clear analysis of the situation of the (very heterogeneous) communities that will be empowered;

2. Careful selection of target groups; partnerships will be developed with them to ensure that they do not elect those who have been empowered;

3. Mechanisms are established to ensure the involvement of excluded members of the community (marginalized groups), for example the quota for women's membership in local development agencies; and

4. Existing local organizational units adapted to accommodate them to participate in the process of creating new structures.

Multidimensional development activities that result in interdependence between key actors require strong partnerships and must be based on mutual trust and mutual strengthening. Partnership patterns can only be achieved by empowering the virgin elements of the individual, family and society. The community empowerment process is an effort to help people develop their own abilities so that they are free and able to solve problems and make decisions independently. The empowerment process is carried out by providing authority (power), accessibility to resources and an accommodating environment (Zimmerman, 1996. Ress, 1991). The community empowerment approach that is manifested in participatory development is very suitable and can be used to anticipate changes in society and its strategic environment. As a basic concept of participatory development is to make development efforts on the basis of meeting the needs of the community itself so that people are able to develop and overcome their own problems independently, sustainably and sustainably (Sumaryo Gitosaputro, kordyana K. Rangga: 2015: 27-29). Community economic empowerment is a manifestation of increasing the dignity and dignity of society to escape the traps of poverty and underdevelopment. This step is part of increasing the capacity and increasing the economic independence of the community. Community economic empowerment requires active and creative participation. According to Samuel Paul (1987-24), active and creative participation is stated as "participation refers to an active process where by beneficiaries influence the direction and axecution of development projects rather than merely receive a share of project benefits" (participation refers to an active process. in which the target group can influence the direction and implementation of development projects rather than merely receiving the sharing of project benefits). In relation to this definition (Cohen and Uphoff, 1990: 215-23) states that the definition stated by Samuel Paul above views involvement community starting from the stage of decision making, implementing decisions, enjoying results and evaluating. Participation supports the community to start being aware of the situation and the problems it faces. In addition, it also seeks to find solutions that can be used in overcoming the problem. On the other hand, participation also helps the poor in seeing the socio-economic realities and the decentralization process by strengthening the "delivery system" at the grassroots level. Increasing public participation in the economic and political world union is considered very strategic and decisive. On the basis of this viewpoint, community empowerment is closely related to stabilization, culture and the experience of democracy. 
In this context and line of thought Friendmann (in Soetrisno, 1991) stated as follows: the power approach, which is fundamental to alternative development, places the emphasis on outonomy in decision making of territorially organized communities, local self-reliance (but not autarchy), direct (participatory) democtracy and experiential social learning ".

The empowerment approach plays an important role in alternative development, because it places people to gain experience and emphasis on territorial autonomy and community decision-making, local independence (but not autarchy), direct democracy (participatory) and social learning. In the next section, Friedmann as quoted by Soetrisno (1995), also reminds that it is very unrealistic if economic forces and structures outside of civilization are ignored in the assessment of empowerment. Therefore, according to Fredmann, community empowerment is not only limited to economics but also politically, this is what makes society a competitive bargaining position, both nationally and internationally. The empowerment paradigm is motivated to change conditions that are completely centralized to a more autonomous situation. This is done by giving the poor the opportunity to plan and then implement a development program of their own choosing, they are also given the opportunity to manage development funds both from the government and from outside parties. The basic concept of empowerment is called by Friedmann as an alternative development which requires "inclusive democracy, appropriate economic growth, gender equality and intergeranational equality" (inclusive democracy, adequate economic growth, gender equality and equality between generations). Meanwhile, Schumacher (in Soetrisno, 1995) states that the most appropriate strategy to eradicate poverty is to "hook rather than fish" which encourages them to be more independent. Schhumacher provides a special place for the NGO (non-government organization) group in the development process. Schumacher gave the following reasons: a powerment emphasis that focuses more on forming independent groups will not have much meaning without political support, as stated by Freire. That is, whatever powerment concept to choose requires a "political dose" to be a powerful cure for poverty (Soetrisno, 1995).

\section{Natural Resource Theory}

A resource is something that has a use value. Natural Resources (SDA) are all the physical, chemical, biological and social factors that make up our environment. Hunker et al stated that natural resources are all those that come from the earth, the biosphere, and the atmosphere, whose existence depends on human activities. All parts of our natural environment (grains, trees, soil, water, air, sun, rivers) are natural resources. Natural Resources are elements consisting of vegetable SDA (plants) and Animal SDAs (animals) with the surrounding nonliving elements that form an entire ecosystem. Natural resources have a role in meeting human needs. Juridically, the definition of SDA is contained in Article 1 paragraph 9 of Law no. 32 of 2009 concerning Environmental Protection and Management, is SDA is an element of the environment consisting of biological and non-living resources which as a whole forms a unitary ecosystem. There are several opinions regarding the sharing of natural resources. Among other things, in terms of the general nature of the ecosystem, it is divided into two major groups, namely terrestrial natural resources (land) and aquatic natural resources (waters). However, in natural resource management there are generally three types of natural resources known based on their characteristics, namely: 
1. Natural resources that can be recovered (renewable resources), where the flow of resources depends on the management, with some possibility that the supply may decrease, be sustainable or increase. Examples of land, forest and wildlife.

2. Natural resources that cannot be recovered (non-renewable or deposit resources), where the fixed supply and natural resources consist of:

a) Physically the supply will be completely exhausted. Example: coal, petroleum, natural gas.

b) Inventory is decreasing, but can be reused (recycled). Example: metal and rubber groups

3. Natural resources that will not run out (continuous or flow resources), which are available in a sustainable manner, consisting of:

a) Its supply is unlimited and unaffected by human action. Example: solar energy, tidal energy.

b) The supply is unlimited, but is affected by human action. For example: landscapes, natural beauty, space and air. Natural resources (SDA) are a gift from God Almighty that must be managed properly and correctly in order to provide maximum and sustainable benefits to Russia. Development aims to improve human welfare by developing and utilizing existing natural resources. In utilizing natural resources through development, there will always be changes in the ecosystem which in the end have a positive impact (benefit) or a negative impact (risk) on humans again. The greater the benefits to be pursued, the greater the existing risks or new risks.

Natural resource management is intended to maintain and improve environmental quality that is high, safe and humanly guaranteed. It is only in conditions of high environmental quality that people benefit more than environmental risks. More specifically, the definition of natural resource management includes two things as follows:

1. Human efforts in changing the natural resource ecosystem in order to obtain maximum and sustainable benefits.

2. The process of allocating natural resources in space and time to meet human needs by constantly seeking: (a) Consideration between human population and resources' (b) Prevention of damage to natural resources (and the environment).

Therefore the scope of SDA is an inventory of planning, implementation / utilization and control / supervision. Basically, only the SDA that can be recovered / renewable is actually managed, while the non-renewable SDA is only exploited and cannot be regenerated. SDA by its nature can be classified into SDA that can be renewed and SDA that cannot be renewed. SDA that can be renewed is natural resources that can continue to exist as long as its use is not overexploited. Non-renewable SDA is natural resource which is limited in number because its use is faster than its formation process and if used continuously will be depleted such as examples of plants, animals, micro organisms, sunlight, wind, and water. The need for natural resources is increasing due to population growth and development progress. SDA is limited and even decreases. Without conservation or conservation efforts there is a natural resource crisis, decreasing quality, scarce supplies, reduced diversity, etc. 
The use of natural resources is divided based on its characteristics, namely biological and non-living natural resources. Article 12 paragraph 1 of Law No.32 of 2009 states that the use of natural resources is carried out based on the Environmental Protection and Management Plan (RPPLH). Basically all natural resources including living natural resources must be utilized for the welfare of society and mankind in accordance with their capabilities and functions. The utilization must be in such a way as according to Law no. 5 of 1990 concerning Conservation of Biological Resources and their Ecosystems, so that they can take place sustainably for the present and the future. Utilization and conservation as mentioned above must be carried out in a harmonious and balanced manner as a manifestation of the principle of conservation of living natural resources and its ecosystem.

\section{Local Wisdom Theory}

Perhaps in the rich cultural treasures of this diverse nation, in various regions it is found that social capital and local wisdom are found to describe the ability of the community to maintain living conditions through various different forms, but basically have the nuances of efforts to create prosperity. Often the various forms of welfare efforts that appear in the reality of people's lives are based on a philosophy and are part of the realization of the vision of welfare that every society has.

Koentjaraninggrat (1994: 439) states that even the village people with the lowest level of formal education talk a little about this issue, whether interpreted literally to maintain their physical environment or, more deeply, their spiritual environment. In other societies, of course also found the construction of welfare and how to make it happen based on their socio-cultural background. Of course, it is very unfortunate if the potential for welfare that exists in local wisdom is not identified, accommodated and developed. Therefore, based on the local wisdom it contains, each community not only has a coveted ideal society construction which is basically a picture of a prosperous society, but also a way to realize that ideal society even by using local wisdom the community has a subtle and symbolic way to expressing aspirations and even criticisms of unexpected conditions which, if not anticipated, can hinder, even further away from the coveted ideal society (Soetomo, 2014: 63-65).

\section{Maslow's Need Theory}

A Humanistic psychologist named Abraham Maslow developed a theory of personality that is able to influence many scientific fields. Maslow developed a theory that has a high level of practicality so that it is easy to understand. This theory is also called Maslow's theory which describes reality. The content of this theory can be understood easily because it contains features of human experiences or behavior that have been experienced but have never been included in words.

Maslow is a humanistic psychologist where humanists do not believe that humans are stimulated by mechanical forces, conscious instincts (psychoanalysis), or habits (behaviorism). Humanists have a focus on potential. Humans have self-limits and self-potential to reach certain levels of effort or ability. Humans have the creativity to attain consciousness and wisdom. Maslow calls people at his highest levels "self-actualizing people." 
The theory put forward by Maslow, namely the hierarchy theory of basic human needs, is the basis of other scientific developments related to meeting basic human needs. Meeting basic needs is divided into a certain level that prioritizes human needs from the most basic. The following is an explanation of Maslow and his theory.

Since young, Maslow believed that physical strength is the only strong character of a man so he trains his body by lifting weights and hopes to become a muscular and hand some person. However, due to his relaxed face and nerdy looks, he couldn't achieve his wish.

Maslow is very concerned with the question "why don't many people self-actualize when their basic needs are met?" Humanistic psychologists believe that everyone has a strong desire to realize their potential to reach the level of "self-actualization". Maslow has established a framework that provides a way for psychologists to add information. Maslow believed that leadership should not be intervened. This belief underlies his thinking.

Maslow's concept of the hierarchy of human needs originated from his observations of monkey behavior. Based on these observations, Maslow concluded that some needs take precedence over others. For example, water is the main source of life for living things. Living things can survive hunger and not eat, but cannot survive thirst and without water. This is what Maslow called is a basic need which is then arranged into a level of need. Maslow concludes that needs at the next level can be achieved if needs at lower levels are met.

According to Maslow, satisfying needs is driven by motivational forces, namely deficiency growth and motivation growth. Deficiency motivation is an effort made by humans to meet the shortcomings experienced. While developmental motivation is motivation that grows from the basis of the human being to achieve a self-goal based on his capacity to grow and develop. The capacity or ability of each person is different and is innate.

Maslow's Needs Theory is a hierarchical theory of needs containing basic human needs. Humans are positioned as weak and developing creatures, have the potential for an achievement and are influenced by the environment to be able to grow tall, straight, and beautiful. Maslow's hierarchical theory of needs has five levels of basic needs. In order to achieve a higher basic need, human beings do not need to meet the previous level.

Maslow's basic needs are physiological needs, security needs, love, affection and ownership needs, esteem needs, and self-actualization needs. Maslow's hierarchy of needs is arranged to form a triangle where the base has a wider area and is conical upward. The lowest level is the most basic need and continues at the second third level and so on until the highest level at the top of the pyramid.

\section{METHODOLOGY}

The approach used is qualitative with a case study method. This qualitative approach was chosen in order to obtain broader and more in-depth information on matters that are the subject of discussion for which answers must be found. With the hope of getting a clear description in accordance with the facts, not just a fiction. Using the case study method because this incident was an odd event that occurred in another area or place. 


\section{Research Informants}

The informants in this study were obtained from parties who really have the competence according to the research problem such as the Pangkalan Jambu sub-district apparatus, community leaders, farmers, and other sources related to this research problem. The data collected were obtained directly from research informants such as landowners, sub-district officials, community leaders and others.

\section{Data Collection Techniques}

The data collection techniques used were interview, observation and documentation. In connection with qualitative research, the research instrument is the researcher himself.

\section{Interview}

Used to get data and information that is valid and direct from the original source. With interviews, the conversation can be brought to the substance of the research, so that the information collected is truly objective. The interview model used is free guided interviews, where in conducting interviews the researcher does not intentionally direct the questions and answers on the subject matter of the research focus but still uses the interview guide so as to get maximum results.

\section{Observation}

Observation or direct observation where the researcher directly observes the subject and object of the study. So the researchers themselves come to the place or object of research. Without being represented by others.

\section{Documentation}

The required documentation includes written items: books, magazines, documents, photos, diaries, regulations, data in the relevant office and so on. Documents as data sources can be used to test, interpret and even predict events that may arise in the future.

\section{Data Analysis Techniques}

The collected data were analyzed using three steps of data analysis; namely reduction, presentation of data, and drawing conclusions. Data or rough data from the field, both data from observations, interviews, and documentation, process selection, focus attention, abstracting and transforming This process lasts as long as the research is carried out. Data Display After the data is reduced, the data is displayed in the form of tables, graphics or the like to make it easier to understand the data. Conclusion (Verification). Drawing conclusions with inductive thinking, namely from specific things directed to general things to find out the answers to the problems in this study. Done to get and match the answers obtained from the field with actual conditions. Techniques for Guaranteeing the Validity of Data. Triangulation technique is used to see the credibility. It is used to test the credibility of data from various informants, in various ways, and at various times.

\section{RESEARCH RESULT}




\section{Overview of the Research Location}

This research was conducted in Pangkalan Jambu District, which is one of the subdistricts in Merangin Regency, Jambi Province, which is located at Sungai Bujur Sungai Jering Village. Total Population of Pangkalan Jambu lk. 7,184 people consisting of 3674 men and 3511 women.

The livelihoods of the people of Pangkalan Jambu Subdistrict consist of Civil Servants, TNI, POLRI, Private and Farmers who are engaged in agriculture, namely processing paddy fields and secondary crops. The people of Pangkalan Jambu sub-district highly uphold the values of customs where customs are coded syarak and syarak coded Kitabulloh. This means that the people of Pangkalan Jambu are cultured and religious people, a sense of solidarity with each other that can be seen clearly when there are mutual cooperation or celebration activities.

The number of villages in Pangkalan Jambu District consists of eight, namely: Birun Village, Baru Pangkalan Jambu, Bukut Perentak, Tiga Lanes, Bungo Tanjung, Sungai Jering, Kampung Limo and Tanjung Mudo Village.

\section{Description of Research Results}

a. Objective Conditions of Ex-PETI Land in Pangkalan Jambu District

In general, gold mining carried out by individual miners on average is without a license. Because without this permission from the Government, it is said to be Gold Mining Without Permits (PETI).

Based on existing data on the demographics of Pangkalan Jambu District, there is a number of paddy fields consisting of technically irrigated rice fields and rainfed rice / rendengan rice fields.

The data on the state of productive agricultural land / rice fields before and after PETI are as follows:

CONDITION OF AGRICULTURAL LANDS / SAWAH BEFORE AND AFTER (POST) CHARTS

\begin{tabular}{|c|c|c|c|c|c|}
\hline NO & Village & $\begin{array}{c}\text { PRODUCTIV } \\
\text { E LAND } \\
\text { BEFORE } \\
\text { CHARTS (ha) }\end{array}$ & $\begin{array}{c}\text { LAND } \\
\text { DAMAGE } \\
\text { D DUE } \\
\text { TO } \\
\text { CHARTS } \\
\text { (ha) }\end{array}$ & $\begin{array}{c}\text { RECLAMA } \\
\text { TION } \\
\text { LAND FOR } \\
\text { RICE } \\
\text { FIELD }\end{array}$ & $\begin{array}{c}\text { RECLAMA } \\
\text { TION FOR } \\
\text { POOL }\end{array}$ \\
\hline 1 & BIRUN & 75 & 75 & 12 & 3 \\
\hline 2 & $\begin{array}{c}\text { BARU PKL } \\
\text { JAMBU }\end{array}$ & 117 & 67 & 39,3 & 3 \\
\hline 3 & $\begin{array}{c}\text { BUKIT } \\
\text { PARENTAK }\end{array}$ & 182 & 106 & 32 & 1 \\
\hline 4 & $\begin{array}{c}\text { TIGA ALUR } \\
\text { PKL JAMBU }\end{array}$ & 175 & 157 & 14 & 3 \\
\hline 5 & $\begin{array}{c}\text { BUNGO } \\
\text { TANJUNG }\end{array}$ & 165 & 120 & 9 & 1 \\
\hline
\end{tabular}




\begin{tabular}{|c|c|c|c|c|c|}
\hline 6 & $\begin{array}{c}\text { SUNGAI } \\
\text { JERING }\end{array}$ & 137 & 136 & 11 & 2 \\
\hline 7 & $\begin{array}{c}\text { KAMPUG } \\
\text { LIMO }\end{array}$ & 186 & 123 & 15 & 1 \\
\hline 8 & $\begin{array}{c}\text { TANJUNG } \\
\text { MUDO }\end{array}$ & 165 & 20 & 4 & 4 \\
\hline & Total & 1.202 & 804 & 139 & 16 \\
\hline
\end{tabular}

Observing the table above, it turns out that there were 1202 ha of productive land before the existence of Gold Mining Without Permit (PETI) and 804 ha of damaged land due to PETI. Then the amount of land that is cultivated by the community for planting rice is 139 ha (11, $56 \%$ ). Of the existing 1202 ha of land (before PETI) and 139 ha have been reclaimed, there are still 259 ha of land that is not damaged but not yet producing. Furthermore, this 139 ha land needs further research to see how the community's efforts and successes are in cultivating this land. Of course the further hope is that other community members who have not carried out reclamation will be interested in carrying out reclamation in the future.

b. Underlying Factors and Reclamation Process of Ex-PETI Land in Pangkalan Jambu District, Merangin Regency.

1) Factors Underlying Reclamation

What are the things that underlie community members reclaiming Ex-PETI land? Based on the results of interviews with researchers and respondents (R.A-R.I), it can be stated as follows:

a) The condition of Ex-PETI land.

As stated in table 02 above, there were 1202 ha of productive land before the existence of PETI and 804 ha of damaged land due to PETI, then the land cultivated by the community for planting rice was 139 ha. Of the existing 1202 ha of land (before PETI) and 139 ha have been reclaimed, there are still 259 ha of land that is not damaged and has the opportunity to be reclaimed.

Next, this 139 ha land was cultivated by the landowners on the basis of the consideration that the Ex-Peti land was not contaminated with mercury because the results of interviews indicated that the miners did not use mercury in mining.

b) Economic Factors.

Reclamation is carried out considering the increasing daily basic needs. Even though the average community member has obtained the results from PETI, the PETI period for everyone is not that long and the fund sobtained cannot last long and have been consumed and / or used for other purposes. On the other hand, the price of rubber has fallen and it is almost unpredictable and moreover, it does not have other sources of income such as rubber plantations, oil palm plantations, fields and so on. Therefore, cultivating the ex-PETI land into rice fields again is a must. 


\section{c) Environmental Effects.}

Based on the results of interviews with several respondents that they cultivated ex-PETI rice fields because they saw that many people in the surrounding area had done it and felt interested in cultivating their own land and not for fulfilling their basic needs. This means that from an economic perspective, their basic needs have been met based on the mining results they have obtained. There are some people who use the mining products to buy cars to make a living, such as trucks, L300 and so on. For this reason, processing the Ex-PETI land into rice fields again (reclamation) is carried out due to environmental influences.

\section{Reclamation Process}

Based on the interviews of researchers with respondents (R.3), the reclamation process is as follows.

At the beginning, the discovery of how to reactivate the Ex-PETI land was the result of a trial by a resident (R.3) who carried out an experiment in rice cultivation with the following procedures: First, leveling the soil surface / sand / stone humps and so on. This is done by using an escapator where this tool flattens the surface of the land by immersing the rocks (rock and sand) so that the soil and / or mud rises to the surface; second, after the first step is completed, the second step is the implementation of rice planting. In this case, before the rice is planted, of course, you have to prepare the seeds first. Regardless of the type of seed / seed or paddy being prepared, they follow the usual rice planting steps or procedures, namely sowing the seeds and after they are old enough, planting is carried out in the prepared land, then the third step, harvesting. The harvest / results obtained are the same as before the existence of PETI. From this, the desire of other members of the community emerged to try this method and the results were satisfactory. This means that it does not disappoint the community and it is growing until now.

From the information above and based on observations and interviews of researchers with respondents (R.A-R.I), the reclamation process is carried out with the following steps.

a) Preparation.

At the initial stage, the leveling of the soil / sand / stone humps is carried out. This leveling can be done by: (a) based on the initial agreement or agreement between the miner and the land owner. If, for example, it was agreed from the start that after the mining was finished, the next step was for the miners to level the land with an escapator according to the area of land that had been mined; and (b) land leveling by the owner of the land. This must be done because the land owner did not make an agreement with the miners beforehand. If the land owner wants to level it with an escapator, of course, the method is to pay the escapator owner. The length of time that this land can be used for rice cultivation also depends on the state of water availability to inund ate the land. If enough water is available to inund ate the land, then the land can be used directly as usual. This means that if there is enough water, rice can be planted immediately and vice versa if water is not available, it can be years of waiting for the rice fields to be used or planted with rice again.

b) Implementation of planting. 
After the land has been prepared, the following steps are the implementation of rice planting. In this case, before the rice is planted, of course, you have to prepare the seeds first. Regardless of the type of seed / seed or paddy being prepared, they follow the usual rice planting steps or procedures, namely sowing the seeds and after they are old enough, planting is carried out in the prepared land.

The problem is whether the rice planted on ex-PETI land is not damaged? So in this case, based on the author's observations and interviews with several respondents, it turns out that the miners in this land do not use chemical substances as we know them as mercury (mercury) or mercury ( $\mathrm{Hg}$ ). In general (in other places) people suspect that the miners must be using mercury in mining.

According to research results, if miners used mercury during mining, rice plants and so on would not thrive. As the results of trials in the laboratory conducted by the Center for Environmental Health and Disease Control Engineering (BBTKLPP) Surabaya. (TaliwangSuara NTB, 23 July 2019) that rice has been contaminated with mercury of 0.37 milligrams or above the threshold of safe limits above 0.03 milligrams according to established environmental health standards.

It is different in Pangkalan Jambu District as stated by the Respondents (R.A-R.I) that the Miners do not use Mercury in carrying out mining. It has also been researched by ITB lecturers and students several years ago that these researchers have taken samples such as fish in rivers, water in rice fields and also vegetables consumed by residents such as cassava leaves, spinach, kale and so on, and it turns out that the results show that the miners do not use mercury in mining.

c) Results (Income)

Based on data obtained in eight villages in Pangkalan Jambu sub-district, it turns out that their rice conditions are the same between before the PETI operation and after the PETI operation. This means that there is no effect of PETI on rice fertility and the income of the community who process rice fields. The only difference lies in the amount of land that is cultivated, which is very different between before and after the existence of PETI. Some farmers also say that their rice fields really need fertilizer and this actually depends on the location of the rice fields.

With regard to the land area as mentioned above, it is also strengthened by the monograph data of the Pangkalan Jambu sub-district that in the past, there were 1202 ha of productive rice fields (before the existence of PETI) and now, of the eight existing villages, the number of rice fields that have returned to production is 139 ha. . This means that there are still 804 ha of paddy fields damaged by PETI and 259 ha of land that are not damaged but have not yet operated or have not recovered and need to be reclaimed again.

c. The Role of the Government in the Context of Expanding Agricultural Land in the Pangkalan Jambu District, Merangin Regency.

The role of the government in efforts to reclaim agricultural land for community members based on the results of interviews and observations (R.A-R.I) shows that there is very 
little and only on agricultural extension. Based on the results of the author's interviews with several respondents, it was revealed that the efforts to reactivate the former PETI (reclamation) land can be said to be on the initiative of the land owners themselves. Especially if it is seen from the funding that so far the government has never provided assistance in the form of funds for the reclamation of Ex-PETI land.

The government's role, especially in the field of agricultural extension, is a series of activities as assistance and problem solving for agricultural activities in Pangkalan Jambu District, Merangin Regency.

\section{CONCLUSION}

Starting from the previous description and discussion, a conclusion and recommendation can be drawn as follows.

\section{a. Factors Underlying Reclamation}

The factors that underlie the reclamation are (1) the condition of the ex-crates land which is not contaminated with mecury (mercury) because the miners do not use mercury when mining, (b) economic factors where the income of the residents who own the land (rice fields) find it difficult to meet their needs if they do not process the Ex-PETI land into rice fields, and (3) the environmental influence in which the community in Pangkalan Jambu sub-district generally has cultivated their Ex-PETI land into rice fields again so that they are also encouraged to try it.

\section{b. Reclamation Process. There are three stages of the reclamation process, namely:}

1) preparation

At this stage, the surface of the soil / sand / rock is done. This leveling can be done by: (a) based on the initial agreement or agreement between the miner and the land owner. If it has been agreed from the start that after mining has finished, the next step is for the miners to level the land with an escapator according to the area of land that has been mined; and (b) land leveling by the land owner because it was not agreed upon in advance.

2) Implementation of planting

After the land has been prepared, the following steps are the implementation of rice planting. Before rice is planted, the seeds are prepared and after they are old enough, planting is carried out in the prepared land.

3) Results (Income)

Regarding the yield / income obtained, it turns out that the condition of their rice fields is the same between before and after the PETI operation. This means that there is no effect of PETI on rice fertility and the income of the community who process rice fields. The only difference lies in the amount of land that is cultivated and also the problem of fertilizers. There are rice fields that require fertilizer and some don't and this depends on the location of the paddy fields. 


\section{c. Role of Government}

The government's role in efforts to reclaim agricultural land is very small and only exists in agricultural extension which is a series of activities as assistance and problem solving for agricultural activities in Pangkalan Jambu Kaba, Merangin District. It can be said that the effort to reactivate the former PETI land into paddy fields (reclamation) can be said to be at the initiative of the land owners themselves.

\section{REFERENCE}

Abdulhak, I. (2001). Komunikasi Pembelajaran: Pendekatan Konvergensi dalam Peningkatan Kualitas dan Efektivitas Pembelajaran. Bandung: UPI.

----------. (2000). Metodologi Pembelajaran Orang Dewasa. Bandung: Andira. - (2000). Strategi Membangun Motivasi dalam Pembelajaran Orang Dewasa. Bandung: Andira.

Aartsen, J. V., (1953). Ekonomi pertanian Indonesia. Jakarta: Pembangunan.

Azwar, S. (2003). Sikap manusia: Teori dan Pengukurannya. Yogyakarta: Pustaka Pelajar.

Badan Pusat Statistik Kabupaten Merangin (2020). Merangin Dalam Angka. Merangin: BPS

Borg and Gall. (1979). Educational Research, New York: Pinancing. Washington: The Word Bank.

BROWN, V AND CLARKE, V. (2006). Using thematic analysis in psychology. Qualitative Research in Psychology, 3 (2). pp. 77-101.

Brookfield, S. (1984). Adult Learner, Adult Education and the Community. New York and London, Teacher College: Columbia University.

Brunner, J.S. (1966). Toward a Theory of Instruction. Cambrige. Mass: Harvard University Press.

Budiman, A. (2001). Teori pembangunan dunia ketiga. Jakarta: PT Gramedia Pustaka Utama.

Chaplin, J.P. (2009). Kamus Lengkap Psikologi. Jakarta: PT Raja Grafindo Persada.

Conyers, Diana and Hills, Peter. (1984). An Introduction to Development Planning in the Third World. New York: John Willey \& Sons.

Coombs, Philip H. \& Ahmed, Manzoor (1985). Memerangi Kemiskinan di Pedesaan Melalui Pendidikan Non-Formal, alih bahasa oleh Yayasan Ilmu-Ilmu Sosial. Jakarta: CV Rajawali.

Depdiknas. (2003). Life Skills-Pendidikan Kecakapan Hidup. Jakarata: Depdiknas. 
D. Conyers dan Hill. (1984). Perencanaan Sosial di Dunia Ketiga (Terjemahan). Yogyakarta: Gajah Mada University Press.

Gibson, Ivancevich, Donnelly.(1988). Organisasi, Perilaku, Struktur, Proses (Alih Bahasa Nunuk Adiarni). Jakarta: Binarupa Aksara.

Gomes, Faustino Cardoso. (2000). Manajemen Sumber Daya Manusia, Yogyakarta: Andi Offset.

Hamijoyo, S. S., dan Iskandar, Anwas. (1982). Beberapa Catatan tentang Partisipasi Masyarakat. Prasaran pada Seminar Peranan Lembaga Pendidikan dan Guru dalam Pembangunan Masyarakat Desa di IKIP Bandung.

Hidayat, S dan Syamsulbahri, D. (2001). Pemberdayaan Ekonomi Rakyat. Jakarta. Pustaka Quantum.

Lincoln, Yvona S., \& Egon G. Guba (1985). Naturalistik Inquiry. Beverly Hill: Sage Publication.

Mardikanto, T., (2009). Sistem Penyuluhan di Indonesia. Surakarta: UniversityPress.

Maslow, AH. (1970). Motivation and Personality. New York: Harper and Row Publisher.

Mc. Millan, James H. dan Schumacher, Sally.(2001). Research in Education, Fifth Edition. New York: Longman.

Mulyanto, B. (2008). Hubungan fungsi tanah dan kelembagaan pengelolaan kawasan pasca tambang. Makalah disampaikan dalam Seminar dan Workshop Reklamasi dan Pengelolaan Kawasan Tambang Pasca Penutupan Tambang. Pusat Studi Reklamasi Tambang. LPPM-Institut Pertanian Bogor. Bogor, 22 Mei 2008.

Napier, R. W., \& Gershenfeld, M. K. (1999). Groups: Theory and experience (6th ed.). Boston: Houghton Mifflin.

Mulyadi, (2006). Ekonomi sumberdaya manusia dalam perspektif pembangunan. Jakarta: PT Raja Grafindo Persada.

Nopriadi, (2016). Dampak aktivitas penambangan emas tanpa izin (peti) terhadap pencemaran air sungai, sosial ekonomi, dan solusinya di kabupaten kuantan singingi.

Prosiding Seminar Nasional "Pelestarian Alam \& Mitigasi Bencana" Pekanbaru.

Napitupulu, W.P. (1979). Nonformal Education Strategies and Management. Jakarta: Depdikbud.

Nasution, S. (1988). Metode Penelitian Naturalistik Kualitatif. Bandung: Tarsito.

Putong, Iskandar, (2008). Economics: Pengantar Mikro dan Makro. Jakarta: Mitra Wacana Media. 
Rogers, Everett M. (1985). Communicatiuon Technology. New York: The Free Press. Macmillan Publishing CO., Inc.

Rogers. (1994). Teaching Adults. Milton Keynes-Philadelphia:OpenUniversity Press.

Rogers, dkk. (1988). A Conceptual Variable Analysis of Technological Change: Rural Sociology. New York: The Free Press.

Siagian, SP. (1996). Manajemen Sumber Daya Manusia. Bandung: Bumi Aksara.

Siegel, S. (1986). Statistik Non Parametrik. Jakarta : PT. Gramedia.

Simamora, H. (2004). Manajemen Sumber Daya Manusia. Yogyakarta: STIE YPKN.

Singarimbun, Mari, dan Effendi, Sofian. (1989). Metode Penelitian Survei. Jakarta: LP3S.

Soedomo, M. (1989). Pendidikan Luar Sekolah Ke Arah Pengembangan sistem Belajar Masyarakat. Jakarta: P2LPTK-Depdikbud.

Soelarso, S.W. (2008). Perencanaan reklamasi dan penutupan tambang sebagai bagian integral perencanaan tambang. Makalah disampaikan dalam Seminar dan Workshop Reklamasi dan Pengelolaan Kawasan Tambang Pasca Penutupan Tambang. Pusat Studi Reklamasi Tambang. LPPM-IPB. Bogor, 22 Mei 2008.

Sudantoko, Djoko dan Hamdani, Muliawan. (2009). Dasar-dasar Pengantar Ekonomi Pembangunan. Jakarta Selatan: PT. PP. Mardi Mulyo.

Sudrajat, Akhmat. (2008). Pengertian Pendekatan, Strategi, Metode, Teknik, Taktik, dan Model Pembelajaran [Online], tersedia: http://www.psb-psma. org/content/blog/pengertianpendekatan-strategi-metode-teknik-taktik-dan-model-pembelajaran. [25 Oktober 2020].

Soekanto, S. (1985). Sosiologi Suatu Pengantar. Jakarta: Rajawali.

Sumantri, S. (2000). Pelatihan dan Pengembangan Sumber Daya Manusia. Bandung: Fakultas Psikologi Unpad.

Suwondo, Kutu. (1998). Struktur Sosial dan Kemiskinan. Salatiga: Yayasan Bina Dharma.

Soetomo. (2014). Pemberdayaan Masyarakat. Jakarta: Prestasi Pustaka Publisher.

Trianto. (2007). Model-Model Pembelajaran Inovatif Beorientasi Konstruktif Konsep, Landasan Teoritis dan Implementasinya. Jakarta: Prestasi Pustaka Publisher.

Trimiska, Lesta, dkk., (2019). Kajian Penambangan Emas Tanpa Izin (PETI) di Kecamatan Lebong Utara Kabupaten Lebong.

https://ejournal.unib.ac.id/index.php/naturalis/article/view/9259, tanggal 28 September 2020 . 
UU No. 32 tahun 2009 tentang Perlindungan dan Pengelolaan Lingkungan Hidup.

Veithzal Rivai, (2004). Manajemen Sumber Daya Manusia Untuk Perusahaan. Jakarta: PT. Raja Grafindo Persada.

Wijatno, Serian. (2009). Pengantar Entrepreurship. Jakarta: Grasindo.

Yasin Yakin, Addinul. (2004). Ekonomi Sumber Daya dan Lingkungan: Teori dan Kebijaksanaan Pembangunan Berkelanjutan. Jakarta: Akademika Presindo.

Setiawan. (2006). Pengembangan Minat Pada Anak. http://www.siaksoft.com. Data diakses pada Tanggal 28 Oktober 2020.

Zimmerman, Barry J. (1978). Social Learnng and cognition. New York: University Press.

Sutrisno, dan Suciati, (1987), Teknologi Penyediaan Air Bersih. Jakarta: Penerbit Rineka Cipta Karya.

Sutrisno, Edy. (2009). Manajemen Sumber Daya Manusia. Jakarta: Kencana.

Soetrisno, Loekman. (1995). Menuju Masyarakat Partisipatif. Yogyakarta: Kanisius. 